\title{
ANALYSIS OF FISH AUCTION EFFICIENCY IN KENDAL DISTRICT, INDONESIA
}

\author{
Diharjo Eko Slamet ${ }^{\star}$, Boesono Herry, Fitri Aristi Dian Purnama \\ Coastal Resource Studies, Faculty of Marine and Fisheries Sciences, \\ University of Diponegoro, Semarang, Indonesia \\ *E-mail: ekosurameto@yahoo.com
}

\begin{abstract}
Establishment and development of fishing port facilities can be done by improving the efficiency and optimizing the fish auction as a functional facility. The efficiency of fish auction is affected by a number of factors including the management of fish auction, facilities provided in fish auction, and auction activity. This study was conducted to identify the available facilities and analyze the level of efficiency to be later compared to the efficiency of fish auction in Kendal District. This study was administered in July 2018 to five fish auctions in Kendal District which were Karangsari Fish Auction, Bandengan Fish Auction, Tanggul Malang Fish Auction, Sendang Sikucing Fish Auction, and Tawang Fish Auction. This study employed a descriptive method and samples were selected using the purposive sampling technique. The efficiency of Fish Auction was measured using DEA banxia frontier analysis 4.3. The result of the analysis showed that five Fish Auctions Karangsari Fish Auction, Bandengan Fish Auction, Tanggul Malang Fish Auction, Sendang Sikucing Fish Auction, and Tawang Fish Auction reached scores of $100 \%$. Related to the efficiency, output value or auction transaction value was found to be the factor that had the strongest influence on the score.
\end{abstract}

\section{KEY WORDS}

Efficiency, fish auction, data evelopment analysis, economy.

The north coast of Kendal District belongs to the coastal area in Central Java province. There were seven sub-district are parts of the coastal area that spreads up to 42 kilometres long. Kendal district ranked $8^{\text {th }}$ among 17 other coastal areas in Central Java in the terms of the extent of the sea area. This fact implies that coastal areas in Kendal have the potentials to be further developed (Apriliani, 2014).

The fishing territory of Kendal District covers the north Java Sea that spreads up to 42.2 kilometres, covering 7 subdistricts including: Kaliwungu Subdistrict, Brangson Subdistrict, Kendal City Subdistrict, Patebon Subdistrict, Cepiring Subdistrict, Kangung Subdistrict, Rowosari Subdistrict. Kendal City has 5 fish auction centers which are: Tawang Fish Auction and Sendang Sikucing Fish Auction in Rowosari Subdistrict, Bandengan Fish Auction and Karangsari Fish Auction in Kendal City Subdistrict, and Tanggul Malang Fish Auction in Patebon Subdistrict (Central Bureau of Statistics, 2017).

Fish Auction Place is where fish are sold and this place becomes a factor that can drive and improve the business, and increase fishermen's welfare (Wiyono, 2005). The performance efficiency ofa fish auction site can not be separated from its facilities and infrastructure. The Government has arranged a set of requirements of a fish auction site in the Decree of the Minister of Marine Affairs and Fisheries of the Republic of Indonesia Number 52A / KEPMEN-KP / 2013 on the Control of Quality Assurance System and Fishery Product Security in Production, Processing and Distribution Process. There are ten requirements related to thequality of the fish auction building up to the standard means or tools to supportfish auction activities which can be used as a reference in measuring the efficiency of a fish auction site and to identify the aspects that need improvement.

There are several factors that influence the efficiency of a fish auction including the management of the fish auction site, facilities, and the auction activity itself. Failure in fulfilling any of the requirement might give negative influence on the efficiency of a fish 
auction. Hence, a thorough study should be conducted to measure the performance and efficiency of fish auctions to identify which factors that still have to be improved.

This study analyzed the performance and efficiency of fish auctions in Kendal District including Karangsari Fish Auction, Bandengan Fish Auction, Tanggul Malang Fish Auction, Sendang Sikucing Fish Auction, and Tawang Fish Auction.The objectives of this study include:

1. Identifying the available facilities in fish auction sites in Kendal District;

2. Analyzing fish auction sites in Kendal District;

3. Comparing the efficiency of fish auction sites in Kendal District.

\section{MATERIALS AND METHODS OF RESEARCH}

This study was conducted using a descriptive method through direct observation done to observe various aspects in order to obtain accurate description of the empirical condition of fish auctions. In this study, as a decision maker, the researcher analyzed the condition and problems that occurred in fish auctions. According to Supranto (2003), the descriptive method is an explorative method that allows researchers to describe certain object within certain period of time which results can be used as considerations in decision making.

Primary data and secondary data were analyzed in this study. Primary data were collected through observation and documentation. Observations were conducted to obtain primary data related to the system that applied in fish auctions. The secondary data of this study were retrieved from fish auction sites and the Department of Marine and Fisheries of Kendal District.

Observation, literature review, interview and documentation were administered towards fish auction sites to collect the intended data.

The samples of this study were selected using a purposive sampling method. Munir (2011) stated that purposive sampling method is a sampling method that allows researchers to select samples based on certain characteristics. The respondents of this research were fishermen, fishmongers, and the heads of fish auctions.

The method employed to analyze the quality facilities in fish auction was in accordance with the Decree of the Minister of Marine and Fisheries of Indonesia Number 52A/KEPMENKP/2013 on the Control of Quality Assurance System and Fishery Product Security in Production, Processing and Distribution Process consisting of these following criteria.

- Well-protected with easy-to-clean walls;

- Waterproof floor that is easy to clean, completed with sanitary channels and hygienic liquid waste system;

- Proper lighting that allows the officers to monitor the activities;

- Prohibition on vehicles that smoke out and animals from entering the fish market/grocery;

- Regular cleaning at least once after auction activities over;

- Completed with important warnings such as no smoking, no spitting, no food and beverage signs that should be put in strategic places;

- Adequate clean water supply;

- Product storages that are clean, stainless, watertight and easy-to-clean;

- Shelter waste treatment.

The analysis of fish auction efficiency was done using DEA (Data Envelopment Analyst) method. According to Susilowati and Ikhwan (2004), the analytical technique can be used to analyze the efficiency level of fish auction management through non-parametric DEA (Data Evelopment Analysis) approach, which is a linear-programming based technique. The concept of DEA is to measure the relative efficiency scores of certain economic activity units (UKE) involving other inputs and UKEwithin the same type of input and output. In DEA, the relative efficiency of UKE is defined as the weighted output / weighted input ratio.

Analysis was administered to a number of input factors that affect the output of fish auction sites in the form of fish transaction value (Rp). These input factors include the size of 
thefish auction floor area (m2), the number of personnels (person), the number of auctioneer (person), the number of sellers (person), the number of scales, the number of fishermen (person), the number of fishing tools and the length of the dock $(\mathrm{m})$. A fish auction is said to be efficient if it reaches a hundred percent score. Therefore, factors that affect the efficiency of fish auctioninclude the value of input and output variables.

The obtained data were then calculated using Baxia Frontier Analysis software by counting the efficiency score from each Economic Activity Unit (UKE) or the fish auction. If the score is equal to $100 \%$, then the fish auction is considered efficient, vice versa. According Paramita et.al (2006), to enhance the efficiency of a fish auction, improvement should be administered to the existing input - output based on the potential improvement value obtained in DEA in reference with other fish auctions which have been considered efficient.

\section{RESULTS AND DISCSSION}

General Overview of the Location. According to the Central Bureau of Statistics (2017), Kendal District is one of 35 districts / cities within the Province of Central Java which geographical position lies between 109040 '- 1100 18' East Longitude and 6032 '- 70 24' South Latitude. The southern part of Kendal District is bordered by Java Sea. Its southern part is adjacent to Semarang city, south of Temanggung District and the west by Batang District.

The topography of Kendal Regency includes ocean, lowland and highland which have enough potential resources to be explored, including fisheries. This study is expected to provide a significant contribution for the development of Kendal District.

The Condition of Capture Fisheries. Kendal District has five capture fisheries centers as seen from the presence of fish auction sites in every fish dock areas in some sub-district along the coast line. Fish auction is the center of fish capture by local fishermen and entrant fishermen. The five fish auction are:

1. Fish Auction Karangsari in Sub-district ofKendal City;

2. Fish AuctionBandenganin Sub-district of Kendal City;

3. Fish AuctionTanggul MalanginPatebon Sub-district;

4. Fish AuctionSendang SikucinginRowosari Sub-district;

5. Fish AuctionTawanginRowosari Sub-district.

Aspects that relate to fish auction in Kendal District are regulated under the Regional Regulation Number 10 of 2010 on the Management and Retribution of Fish Auction Sites. Before the enactment of the regulation, fish auctions in Kendal were directly under the management of the Province, particularly the Department of Marine and Fisheries of Central Java. Later in 2010, the management of fish auction sites started to be managed by the regional government. Fish auctions are currently under the management of the Department of Marine and Fisheries of Kendal District.

Generally, the give fish auctions in Kendal District share similar characteristics. The auction sites are where fishermen sell their fish captures and other fishing activities.

The common fish sold in fish auctions of Kendal include anchovies, mackerel, pony fish, sardines, and squid. The capture fish sold in five fish auctions in Kendal in the past five years presented in Figures 1-2.

The production capacity of fish capture in Kendal District from $2013-2017$ tend to increase. The lowest production occurred in 2013 as much as $1.822 .807 \mathrm{~kg}$ which later increased in 2014. The highest production occurred in 2017 reaching up to $3.525 .101 \mathrm{~kg}$. Tawang Fish Auction and Sendang Kucing Fish auction had the highest amount of fish production. Demersal fish that are often found in Kendal District include beltfish (Trichiurus $s p$ ), stingray (Trigon $s p$ ), and spiny turbot Psettodessp). While pelagic fish that are often found there are anchovy (Stolephorus $s p$ ), Spanish mackerel (Scomberomorus $s p$ ), tuna (Auxis sp), and mugil (Valamugil sp).

Tawang Fish Auction is a capture fishery center dominated by the use of Purse seine waring and Arad fishing boats. While the other four fish auctions namely Sendang Sikucing, 
Malang, Bandengan and Karangsari fish auctions were dominated by fishermen who operated outboard motors under 10 GT and employed fishing equipment such as shrimp nets, Gill Net, Dogol and Rampus Net.

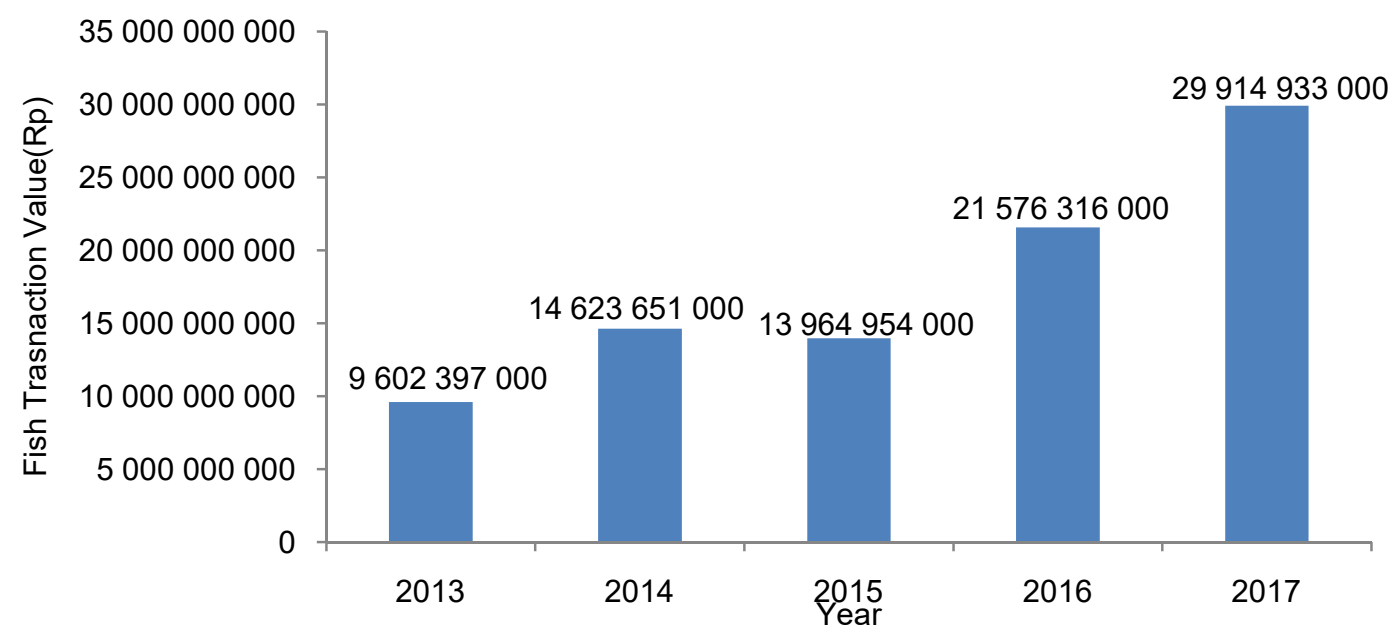

Figure 1 - The Chart of Fish Transaction Value in Fish Auctions in Kendal District

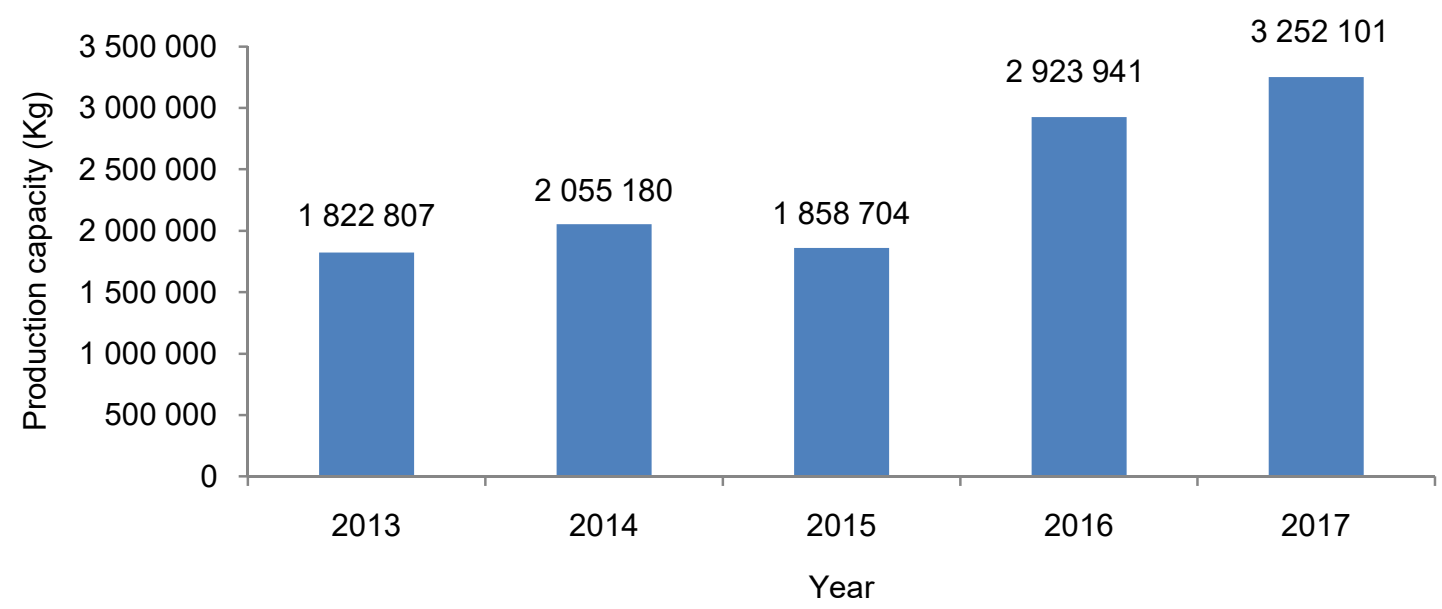

Figure 2 - The Chart of Production Capacity of Fish Auctions in Kendal District

The analysis of facilities and infrastructure at this fish auction site was done based on the Decree of the Minister of Marine Affairs and Fisheries of the Republic of Indonesia Number 52A / KEPMEN-KP / 2013 on Control of Quality Assurance System and Fishery Product Security in Production, Processing and Distribution Process.

Table 1 - The Analysis of Facilities in Fish Auctions in Kendal District

\begin{tabular}{|c|c|c|c|c|c|}
\hline \multirow[t]{2}{*}{ Indicator } & \multicolumn{5}{|c|}{ The Condition of Fish Auctions } \\
\hline & Karangsari & Bandengan & Tanggul Malang & Sendang Sikucing & Tawang \\
\hline 1 & $\sqrt{ }$ & $\sqrt{ }$ & $\sqrt{ }$ & $\sqrt{ }$ & $\sqrt{ }$ \\
\hline 2 & + & + & + & + & + \\
\hline 3 & + & + & + & + & + \\
\hline 4 & v & $\sqrt{ }$ & v & $\sqrt{ }$ & $\sqrt{ }$ \\
\hline 5 & $\checkmark$ & $\sqrt{ }$ & $\sqrt{ }$ & $\sqrt{ }$ & $\sqrt{ }$ \\
\hline 6 & + & + & + & + & + \\
\hline 7 & & & & - & - \\
\hline $\begin{array}{l}8 \\
9\end{array}$ & + & + & + & + & + \\
\hline $\begin{array}{l}9 \\
10\end{array}$ & - & - & - & & - \\
\hline
\end{tabular}

Source: Research Data 2018.

Notes: $\sqrt{ }$ : Facility is available in a good condition as described by the indicator; +: Facility is available in a poor condition as described by the indicator; -: Facility is not available. 
These indicatos were used to define whether the facilities and infrastructure had met the criteria. The following Table 1 is the description of the analysis of facilities and infrastructure in fish auctions.

Indicators:

- Well-protected building with easy-to-clean walls;

- Waterproof and easy-to-clean and easy-to-sanitize floor completed with good drainage system and hygienic liquid waste disposal system;

- Equipped with sanitary facilities such as washstand and enough number of toilettes;

- There should be hand-soap and disposable dryer in the washstand;

- Adequate lighting that enables officers to monitor the activities;

- The prohibition of smoky vehicle and animals from entering the fish market;

- Regular cleaning at least once after auction activities over;

- Completed with important warnings such as no smoking, no spitting, no food and beverage signs that should be put in strategic places;

- Adequate clean water supply;

- Product storages that are clean, stainless, watertight and easy-to-clean;

- The provision of shelter waste treatment.

Based on Table 1, the facilities and infrastructure in five fish auctions in Kendal Regency still suffer from some weaknesses. The description of infrastructure facilities in fish auctions in Kendal District is presented as follows:

- Well-protected building with easy-to-clean walls. The five fish auctions have good quality open building with high roof in the form of ceiling, asbestos, and roof tile, allowing the air in the building to be well-circulated. This type of building prevents stuffy air and fishy smell;

- The five fish auctions have waterproof floor and sewerage. The condition of the auction floor in the fish auction has been considered clean enough and no puddle was found in the channels. According to Murdianto (2003) the floor of auction building should be spacious with smooth but hard and dense and easily-to-dry surface;

- Every fish auction has been competed with toilettes. However, sanitary facilities such as washstand was not yet available in every fish auction site;

- Sufficient lighting to facilitate the auction activities. Auction activity in TPI in Kendal District is done in the morning and afternoon. The open building allows sunlight to go through and lamps are turned on in the night;

- Vehicles that exclude smoke and animals might also affect the quality of fishery products, and they should be banned from entering the fish auction site. The presence of animals in fish auction greatly affects the quality of the catch. Therefore, animal should not enter the fish auction area;

- All fish auctions in Kendal District keep their sites clean as they are cleaned using freshwater everyday;

- Warning signs were not available;

- All fish auction have adequate clean water supply. The sites provide sufficient clean water to support auction activities such as for cleaning the catch and cleaning the building. However, none of those fish auction provides clean seawater;

- All of those fish auctions do not have clean, rust-proof, water-resistant and easy-toclean container;

- Waste shelters were also not provided by those fish auctions.

The efficiency of fish auctions was analyzed using a program namely 'Software Banxia Frontier Analyst ". There were eight input variables put into the analysis including the floor area of the auction (m2), the number of auction personnels (person), number of auctioneer (person), number of sellers (person), number of scales (unit), number of fishermen (person) catch tools (unit), and length of dock $(\mathrm{m})$. Meanwhile, the output factor was the production value $(\mathrm{Rp})$.

Based on the results of the analysis, all five fish auctions obtained $100.00 \%$ (Karangsari Fish Auction, Bandengan Fish Auction, Malang Fish Auction, Sendik Sikucing 
Fish Auction and Tawang Fish Auction). Within this condition, the value between the target and the potential value was $0 \%$ improvement since the input has been in accordance with the expected output.

\section{CONCLUSION AND SUGGESTIONS}

Some of the existing facilities and infrastructure at the fish auction sites in Kendal Regency are in good condition since complete and adequate facilities have been established. The efficiency level of fish auctions in Kendal District based on result of calculation using DEA baxia frontier analysis 4.3 showed 100\% score (Karangsari Fish Auction, Bandengan Fish Auction, Malang Fish Auction, Sendik Sikucing Fish Auction and Tawang Fish Auction. Within this condition, the value between the target and the potential value was $0 \%$ improvement since the input has been in accordance with the expected output.

Suggestions:

- It is necessary to improve and equip the infrastructure and facilities in fish auctions to support auction activities. It is suggested that the floors are made of ceramics, and the sites should be competed with clean water taps, drains and trash bin to maintain the cleanliness of the sites;

- It is suggested that more sellers participate in the auction in order to keep the price competitive;

- Other factors that contribute to the efficiency of fish auctions should also be improved.

\section{REFERENCES}

1. Apriliani, K.F. 2014. Analisis Potensi Lokal di Wilayah Pesisir Kabupaten Kendal dalam Upaya Mewujudkan Blue Economy. Economics Development Analysis Journal. 3(1):5969.

2. Badan Pusat Statistik. 2017. Statistik Tempat Pelelangan Ikan 2016/2017. BPS Kabupaten Kendal. Kendal.

3. Badan Pusat Statistik. 2017. Kabupaten Kendal Dalam Angka 2017. BPS Kabupaten Kendal. Kendal.

4. Munir. 2011. Metode Penelitian. Gramedia Pustaka Utama. Jakarta.

5. Murdiyanto, B. 2003. Pelabuhan Perikanan. Institut Pertanian Bogor.

6. Pramitasari, S.D., Anggoro, S.I. \& Susilowati. 2006. Analisis Efisiensi TPI (Tempat Pelelangan Ikan) Kelas 1, 2 Dan 3 di Jawa Tengah dan Pengembangannya Untuk Peningkatan Kesejahteraan Nelayan. Jurnal Pasir Laut. 1(2):12-21.

7. Supranto. 2003. Metode Riset. Jakarta: Rineka Cipta.

8. Susilowati, I. \& Ikhwan, M. 2004. Petunjuk Pengukuran Efisiensi Melalui Data Envelopment Analysis (DEA). Universitas Diponegoro.

9. Wiyono, W. 2005. Peran dan Strategi Koperasi Perikanan dalam Menghadapi Tantangan Pembangunan TPI dan PPI di Indonesia Terutama di Pulau Jawa. Makalah dalam Semiloka Internasional tentang Revitalisasi Dinamis Pelabuhan Perikanan dan Perikanan Tangkap di Pulau Jawa dalam Pembangunan Indonesia. Bogor. 